\title{
Article \\ Polycyclic Aromatic Hydrocarbons in the Atmosphere of the Southern Baikal Region (Russia): Sources and Relationship with Meteorological Conditions
}

\author{
Irina Marinaite $\left.{ }^{1, *} \mathbb{(}\right)$, Ioganes Penner ${ }^{2}$, Elena Molozhnikova ${ }^{1}$, Maksim Shikhovtsev ${ }^{1}$ and Tamara Khodzher ${ }^{1}$ \\ 1 Limnological Institute, Siberian Branch of the Russian Academy of Sciences, Ulan-Batorskaya Str. 3, \\ 664033 Irkutsk, Russia; yelena@lin.irk.ru (E.M.); max97irk@yandex.ru (M.S.); khodzher@lin.irk.ru (T.K.) \\ 2 V.E. Zuev Institute of Atmospheric Optics, Siberian Branch of the Russian Academy of Sciences, Academician \\ Zuev Square 1, 634055 Tomsk, Russia; penner@iao.ru \\ * Correspondence: marin@lin.irk.ru
}

check for

updates

Citation: Marinaite, I.; Penner, I.;

Molozhnikova, E.; Shikhovtsev, M.; Khodzher, T. Polycyclic Aromatic

Hydrocarbons in the Atmosphere of the Southern Baikal Region (Russia):

Sources and Relationship with

Meteorological Conditions.

Atmosphere 2022, 13, 420. https: / /

doi.org/10.3390/atmos13030420

Academic Editor: Rafael Borge

Received: 28 January 2022

Accepted: 2 March 2022

Published: 5 March 2022

Publisher's Note: MDPI stays neutral with regard to jurisdictional claims in published maps and institutional affiliations.

Copyright: (C) 2022 by the authors. Licensee MDPI, Basel, Switzerland. This article is an open access article distributed under the terms and conditions of the Creative Commons Attribution (CC BY) license (https:// creativecommons.org/licenses/by/ $4.0 /)$.

\begin{abstract}
This article presents the results of the long-term studies at two stations located in the city of Irkutsk and the Listvyanka settlement of the southern Baikal region (East Siberia) concerning the concentration of polycyclic aromatic hydrocarbons (PAHs) in atmospheric aerosol. The studies revealed the seasonal and interannual dynamics in the distribution of PAHs in aerosols from urban (source) and rural (receptor) areas. We carried out a comprehensive analysis of weather conditions such as wind direction, relative humidity, air temperature, and atmospheric pressure. The analysis determined high correlations between air temperature, atmospheric pressure, temperature inversions, and PAHs at the monitoring stations. The average annual concentrations of PAHs in the abnormally warm 2020 were three times lower than the average values obtained in the cold 2016. The toxic equivalent concentrations (BaPeq) increased from summer to winter with an increase in the contribution from benzo(a)pyrene, one of the most toxic and hazardous compounds of this class of organic substances. Four-, five- and six-ring PAHs mainly predominated in aerosol; the proportion of twoand three-ring PAHs increased from the warm season to the cold season. Diagnostic ratios of PAHs identified the main sources of air pollution by this class of compounds: combustion of coal, liquid fuel and firewood, vehicle emissions, and wildfires. The percentage of the transport of anthropogenic aerosol containing PAHs from industrial sources of the Southern Baikal region towards Lake Baikal was 65 to $71 \%$.
\end{abstract}

Keywords: PAHs; meteorological parameters; seasonal dynamics; sources; transport

\section{Introduction}

Currently, much attention has been paid to the protection of Lake Baikal and the Baikal natural territory from the negative impact of anthropogenic factors [1]. The Southern Baikal region is one of the most developed industrial areas of the Irkutsk Region, which is part of the zone of atmospheric influence on the ecosystem of Lake Baikal [2]. In 2018, the priority list of cities with the highest levels of air pollution in the Russian Federation included 22 cities, six of which are situated in the Irkutsk Region (Angarsk, Usolye-Sibiskoye, Cheremkhovo, Irkutsk Shelekhov, and Bratsk) [2]. The high level of air pollution in these cities is due to the great contribution from organic pollutants such as polycyclic aromatic hydrocarbons (PAHs). These compounds are classified as environmental supertoxicants of hazard class 1because many of them have mutagenic and carcinogenic properties. Sources of PAHs are emissions from thermal power plants, oil refineries, non-ferrous metallurgy, small boiler houses, residential districts with stove heating, and vehicles. In recent years, with the growth of wildfires in the boreal forests of Siberia, the role of this source in the atmosphere has been increasing during spring and summer [3]. 
To monitor air quality and reduce the impact of these toxic chemical substances on humans, PAH sources can be analysed using their diagnostic ratios [4-9]. In the atmosphere, PAHs mainly sorb on solid aerosol particles. The sizes of aerosol particles largely determine their further behaviour in the atmosphere, air mass transport in the direction of dominant winds, deposition on the underlying surface, and accumulation in various natural environments.

In the 1990s, an international monitoring network covering more than ten cities in Japan, China, and Korea was established to continuously monitor PAH concentrations in the atmosphere [10]. In large cities of Russia, PAHs are also monitored in the atmosphere but with the determination of only benzo(a)pyrene, the most toxic element. Its average daily level in the atmosphere should not exceed $1 \mathrm{ng} / \mathrm{m}^{3}$ [11], although, in the cities of Russia and China [12], there are extremely high concentrations of these compounds in winter, which is mainly associated with the emissions from coal-fired thermal power plants. However, the concentration of PAHs in the atmosphere depends not only on the amount and capacity of sources but also on the meteorological conditions that are unfavourable for the dispersion of pollutants. Currently, two monitoring stations, Irkutsk and Listvyanka, for determining a large number of PAH compounds discussed in this article have been established, which are located in different physicochemical conditions and have a different degree of anthropogenic impact.

This study aimed to analyse seasonal and interannual dynamics of PAH concentrations in the atmosphere of the Southern Baikal region, to determine the relationship with meteorological conditions in the region and to assess the transport of environmental toxicants to the Baikal basin from regional sources. This article presents the first results on the assessment of the pollution of the ground atmospheric layer with 20 PAHs. The diagnostic ratios of these PAHs allowed us to determine PAH sources and to evaluate the toxic risk posed by these environmental toxicants. The Hybrid Single-Particle Lagrangian Integrated Trajectory model (HYSPLIT) estimated the proportion of the air mass transport from large industrial sources towards Lake Baikal as part of atmospheric aerosol, in which we determined PAHs as well as their seasonal and interannual dynamics.

\section{Materials and Methods}

\subsection{Sample Collection}

The first reference station for the sampling of atmospheric aerosol for PAHs was located in a residential area of Irkutsk (52.248540 E, 104.260441 N), on the balcony of the fourth floor at Limnological Institute (Figure 1). Irkutsk, with a population of approximately 62,000 citizens, is included in the list of the most ecologically unfavourable cities in Russia. The pollution sources of the city include emissions from the large thermal power plant, low-capacity coal-fired boiler houses, stove heating of about 30 thou houses, exhaust gases of vehicles, and some local enterprises (aviation plant and aluminium smelter). Another sampling station was located $70 \mathrm{~km}$ from Irkutsk on the southwest coast of Lake Baikal, in the Listvyanka settlement (51.847129 E, 104.893475 N), $670 \mathrm{~m}$ above sea level (Figure 1). This station is classified as rural. Atmospheric aerosol was sampled at the top of the coastal hill $1 \mathrm{~km}$ from the road and the border of the settlement. Aerosol was sampled on glass-microfibre filters (Munktel, Hampton, VA, USA, d-47 mm) using a sampler with a small volume of air pumping (ModelPU-4E). Atboth stations, average weekly samples were taken, i.e., four samples were taken each month. Sampling was carried out by the seasons of the year from October 2015 to March 2017 and from September 2019 to February 2021. Before the analysis, filters were stored in a freezer at a temperature of $-20^{\circ} \mathrm{C}$. 


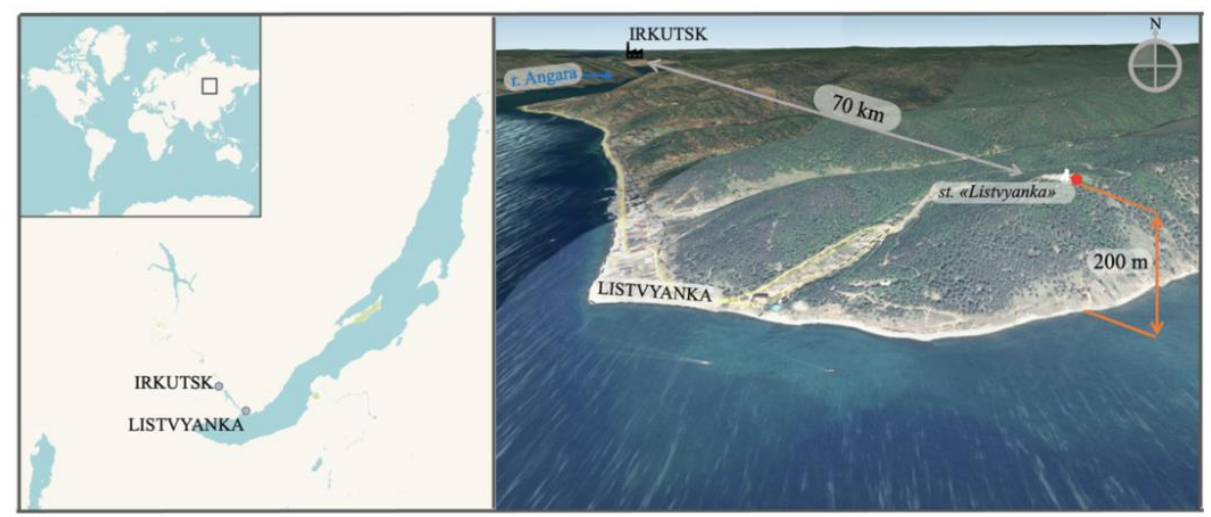

Figure 1. Schematic map of the layout of the stations for sampling aerosol for PAHs in the Southern Baikal region, Russia: the city of Irkutsk — urban area and the Listvyanka settlement—rural area.

\subsection{Determination of PAHs}

For the determination of PAHs, $20 \mu \mathrm{L}$ of the internal standard were added to the filters. The internal standard contained a mixture of denudated PAHs: naphthalene-d8, acenaphthene-d10, phenanthrene-d10, chrysene-d12, and perylene-d12 (in a mixture of n-hexane: acetone (1:1); $1 \mathrm{ng} / \mu \mathrm{L}$ (Supelco, Bellefonte, PA, USA). PAHs from the filters were extracted with n-hexane in an ultrasonic bath for $20 \mathrm{~min}$. The aliquots of the extract, $\sim 1 \mathrm{~mL}$, were taken and transferred to chromatography vials for analysis. The samples were analysed by gas chromatography mass spectrometry (Agilent Technologies 7890B GC System 7000C GC-MS Triple Quad chromatograph mass spectrometer, Santa Clara, CA, USA). The analytes were separated using an OPTIMA ${ }^{\circledR} 17$ MS Macherey-Nagel capillary column $(30 \mathrm{~m} \times 0.25 \mathrm{~mm} 0.25 \times \mu \mathrm{m})$. The column temperature mode was as follows: $50^{\circ} \mathrm{C}$ for $0.5 \mathrm{~min}$, then heating from 50 to $310{ }^{\circ} \mathrm{C}$ at $20{ }^{\circ} \mathrm{C} \mathrm{min}-1$ (isothermal for 15 to $20 \mathrm{~min}$ ). The amount of PAHs in the filters was determined based on the internal standard method. Qualitative and quantitative determinations were carried out for the following priority pollutants: naphthalene (Nap), 2-methylnaphthalene (2-MetNap), 1-methylnaphthalene (1MetNap), acenaphthene (AcPy), acenaphthylene (Acp), fluorine (Flu), phenanthrene (Phe), anthracene (Ant), fluoranthene (FluT), pyrene (Pyr), benz(a)anthracene (BaA), chrysene $(\mathrm{Chr})$, benzo(b)fluoranthene $(\mathrm{BbF})$, benzo(k)fluoranthene $(\mathrm{BkF})$, benzo(e)pyrene $(\mathrm{BeP})$, benzo(a)pyrene (BaP), perylene (Per), indeno(l,2,3-cd)pyrene (IcdP), benzo(g,h,i)perylene (BghiP), and dibenz $(\mathrm{a}, \mathrm{h})$ anthracene (DahA). The determination limits of PAHs in the filters with aerosol were $0.002-1000 \mathrm{ng} / \mathrm{m}^{3}$. The accuracy of the method used was $20 \%$, and reproducibility $-25 \%$ [3]. The concentrations of PAHs in aerosols are presented in Table 1.

Table 1. Minimum and maximum concentrations of PAHs $\left(\mathrm{ng} \cdot \mathrm{m}^{-3}\right)$ in aerosols from Irkutsk and Listvyanka in different seasons from 2015 to 2021. Average seasonal temperature $\left(C^{\circ}\right)$ in the region and extremal range $\left(\min \sim \max \mathrm{C}^{\circ}\right)$ during the measurements.

\begin{tabular}{|c|c|c|c|c|c|c|c|c|}
\hline \multicolumn{3}{|c|}{ Winter $(n=62)$} & \multirow{2}{*}{\multicolumn{2}{|c|}{$\begin{array}{l}\text { Spring }(n=62) \\
4.2(-29 \sim+27)\end{array}$}} & \multirow{2}{*}{\multicolumn{2}{|c|}{$\begin{array}{c}\text { Summer }(\mathrm{n}=62) \\
17.5(+1 \sim+33)\end{array}$}} & \multirow{2}{*}{\multicolumn{2}{|c|}{$\begin{array}{l}\text { Autumn }(n=62) \\
-1.6(-32 \sim+26)\end{array}$}} \\
\hline $\mathrm{T}\left({ }^{\circ} \mathrm{C}\right)$ & -15.1 & $-39 \sim+6)$ & & & & & & \\
\hline Name & Irkutsk & Listvyanka & Irkutsk & Listvyanka & Irkutsk & Listvyanka & Irkutsk & Listvyanka \\
\hline Nap & $0.05-0.58$ & $0.14-0.3$ & $0.06-0.3$ & $0.07-1.0$ & $0.05-0.10$ & $0.04-0.1$ & $0.03-0.17$ & $0.01-3.0$ \\
\hline 2-MetNap & $0.03-0.31$ & $0.06-0.16$ & $0.03-0.15$ & $0.04-0.13$ & $0.01-0.07$ & $0.03-0.1$ & $0.04-0.12$ & $0.05-0.1$ \\
\hline 1-MetNap & $0.03-0.35$ & $0.05-0.17$ & $0.03-0.15$ & $0.03-0.08$ & $0.01-0.05$ & $0.02-0.08$ & $0.02-0.14$ & $0.01-0.04$ \\
\hline $\mathrm{AcPy}$ & $0.06-1.4$ & $0.01-0.34$ & $0.01-0.28$ & $0.01-0.02$ & 0.01 & 0.01 & $0.01-0.79$ & $0.02-0.05$ \\
\hline Acp & $0.01-0.06$ & $0.01-0.2$ & $0.01-0.02$ & $0.01-0.02$ & 0.01 & 0.01 & $0.01-0.05$ & 0.01 \\
\hline Flu & $0.07-0.41$ & $0.05-6.4$ & $0.04-0.19$ & $0.03-1.0$ & $0.02-0.03$ & $0.01-0.05$ & $0.07-0.23$ & $0.05-0.8$ \\
\hline
\end{tabular}


Table 1. Cont.

\begin{tabular}{|c|c|c|c|c|c|c|c|c|}
\hline \multicolumn{3}{|c|}{ Winter $(n=62)$} & \multirow{2}{*}{\multicolumn{2}{|c|}{$\begin{array}{l}\text { Spring }(n=62) \\
4.2(-29 \sim+27)\end{array}$}} & \multirow{2}{*}{\multicolumn{2}{|c|}{$\begin{array}{c}\text { Summer }(\mathrm{n}=62) \\
17.5(+1 \sim+33)\end{array}$}} & \multirow{2}{*}{\multicolumn{2}{|c|}{$\begin{array}{l}\text { Autumn }(\mathrm{n}=62) \\
-1.6(-32 \sim+26)\end{array}$}} \\
\hline $\mathrm{T}\left({ }^{\circ} \mathrm{C}\right)$ & -15.1 & $-39 \sim+6)$ & & & & & & \\
\hline Name & Irkutsk & Listvyanka & Irkutsk & Listvyanka & Irkutsk & Listvyanka & Irkutsk & Listvyanka \\
\hline Phe & $0.7-9.7$ & $0.6-4.9$ & $0.4-1.9$ & $0.2-2.0$ & $0.30-0.48$ & $0.1-0.4$ & $0.4-5.5$ & $0.4-12$ \\
\hline Ant & $0.09-1.6$ & $0.04-0.3$ & $0.01-1.3$ & $0.01-0.1$ & 0.01 & $0.01-0.02$ & $0.02-0.56$ & $0.02-0.1$ \\
\hline FluT & $2.3-59$ & $0.4-18$ & $0.3-3.7$ & $0.14-0.7$ & $0.12-0.26$ & $0.18-0.45$ & $0.4-30$ & $0.16-6.3$ \\
\hline Pyr & $2.0-53$ & $0.3-16$ & $0.24-3.6$ & $0.1-1.0$ & $0.18-1.2$ & $0.14-0.36$ & $0.25-27$ & $0.13-4.7$ \\
\hline $\mathrm{BaA}$ & $0.1-15$ & $0.1-4.6$ & $0.03-1.0$ & $0.01-0.3$ & $0.01-0.02$ & $0.01-0.05$ & $0.02-6.7$ & $0.1-0.67$ \\
\hline Chr & $0.1-18$ & $0.1-9.0$ & $0.08-1.2$ & $0.04-0.5$ & $0.04-0.3$ & $0.05-0.16$ & $0.36-8.3$ & $0.06-1.4$ \\
\hline $\mathrm{BbF}$ & $0.2-51$ & $0.3-41$ & $0.2-2.3$ & $0.18-0.78$ & $0.07-1.0$ & $0.1-0.72$ & $0.10-21$ & $0.09-6.0$ \\
\hline $\mathrm{BkF}$ & $0.10-29$ & $0.1-17$ & $0.10-1.8$ & $0.1-0.34$ & $0.06-0.13$ & $0.05-0.29$ & $0.10-13$ & $0.07-4.3$ \\
\hline $\mathrm{BeP}$ & $0.13-21$ & $0.2-24$ & $0.13-1.8$ & $0.14-0.55$ & $0.06-0.8$ & $0.10-0.55$ & $0.18-11.7$ & $0.09-4.3$ \\
\hline $\mathrm{BaP}$ & $0.10-27$ & $0.1-8.9$ & $0.03-2.4$ & $0.06-0.14$ & $0.01-0.04$ & $0.03-0.13$ & $0.02-6.8$ & $0.02-1.0$ \\
\hline Per & $0.2-2.8$ & $0.1-8.9$ & $0.03-0.3$ & 0 & $0.01-0.4$ & 0 & $0.1-1.3$ & $0.07-0.15$ \\
\hline IcdP & $1.0-9.0$ & $0.2-5.9$ & $0.08-1.5$ & $0.07-0.17$ & $0.01-0.30$ & $0.06-0.25$ & $0.4-4.2$ & $0.09-1.8$ \\
\hline BghiP & $0.4-6.5$ & $0.2-6.2$ & $0.09-1.4$ & $0.09-0.4$ & $0.02-0.30$ & $0.04-0.30$ & $0.1-3.9$ & $0.5-1.7$ \\
\hline DahA & $0.09-0.70$ & $0.05-0.4$ & 0.0 & 0 & 0.0 & 0 & $0.07-0.3$ & $0.03-0.11$ \\
\hline$\Sigma_{20 \mathrm{PAHs}}$ & $8.1-318$ & 5.3-158 & $1.9-24$ & $3.5-36$ & $1.1-12$ & $1.3-3.4$ & $2.2-89$ & $2.3-37$ \\
\hline $\begin{array}{l}\text { Average annual } \\
\Sigma_{20 \mathrm{PAHs}} \text { in } 2016\end{array}$ & 36 & 11 & & & & & & \\
\hline $\begin{array}{l}\text { Average annual } \\
\Sigma_{20 \mathrm{PAHs}} \text { in } 2020\end{array}$ & 13 & 4 & & & & & & \\
\hline
\end{tabular}

\subsection{Meteorological Parameters and Back Trajectories}

Archived data on high-altitude synoptic maps were borrowed from the website of Arctic and Antarctic Research Institute (AARI) [13]. The weather station of the Irkutsk airport provided the data on weather conditions (ground level air temperature, atmospheric pressure, humidity, wind, and weather events) [14]. The Angarsk weather station provided the data on high-altitude sounding with weather balloons [15].We carried out a statistical analysis of the dependence of the PAH concentrations in the atmosphere on meteorological conditions such as atmospheric pressure, relative humidity, and air temperature.

Back trajectories were calculated using a Hybrid Single-Particle Lagrangian Integrated Trajectory (HYSPLIT) model developed by National Oceanic and Atmospheric Administration, Washington DC [16]. The trajectories were calculated for $96 \mathrm{~h}$ and for the heights of 1200, 3000, and $5000 \mathrm{~m}$ above the ground. Station Listvyanka was chosen as the receptor site. A total of 366 reverse trajectories of air mass movement were built for 2016 and 366 reverse trajectories for 2020.The calculated trajectories were divided into 16 types of atmospheric transport (NW; W-NW; W; W-SW; SW; S-SW; S; S-SE; SE; E-SE; E; E-NE; NE; N-NE; N; N-NW) and "local circulation" (LC).

\subsection{Diagnostic Coefficients}

The diagnostic ratio method (DR) is used to identify PAH sources, and it is based on the suggestion that controlled PAH sources produce emissions, remaining constant over time. For DR calculation, PAHs with the same or close physicochemical properties are used. DRs show the ratios of individual PAHs or PAH groups, e.g., A/ $(A+B)$ or A/B, where A and $B$ are the concentrations of two different PAHs. DRs were used in this study to identify PAH sources according to [4-8,17-19] (Table 2). 
Table 2. Diagnostic indicators of PAHs obtained from 2015 to 2021 in the Southern Baikal region.

\begin{tabular}{|c|c|c|c|}
\hline PAH Ratios & Source Indicator & Irkutsk City & Listvyanka Settlement \\
\hline FluT/FluT + Pyr & $\begin{array}{c}<0.4 \text { Petrogenic } \\
>0.4 \text { Combustion of coal } \\
\text { and wood }[4,9]\end{array}$ & $0.44-0.60(0.49)$ & $1.2-16.9(2.63)$ \\
\hline IcdP/IcdP + BghiP & $\begin{array}{l}>0.5 \text { Combustion of coal } \\
\text { and wood } \\
<0.5 \text { Combustion of liquid } \\
\text { fuel }[4,9]\end{array}$ & $0.41-0.97(0.50)$ & $0.39-0.47(0.46)$ \\
\hline $\mathrm{B}[\mathrm{a}] \mathrm{P} / \mathrm{B}[\mathrm{ghi}] \mathrm{Per}$ & $\begin{array}{c}<0.6 \text { Vehicles [9] } \\
>0.6 \text { Stationary sources [4] }\end{array}$ & $0.6-46.7(2.0)$ & $0.3-1.2(0.49)$ \\
\hline $\mathrm{BeP} / \mathrm{BeP}+\mathrm{BaP}$ & $\begin{array}{c}<0.5 \text { Close sources } \\
>0.5 \text { Distant sources }[4-8]\end{array}$ & $0.4-0.7(0.62)$ & $0.68-0.9(0.74)$ \\
\hline
\end{tabular}

\subsection{Health Risk Assessment}

According to the International Agency for Research on Cancer, the carcinogenic risk posed by individual PAHs was assessed. In the list of priority PAHs, benzo(a)pyrene is classified as the most hazardous carcinogen. Estimates of the toxic hazard posed by PAHs were expressed in arbitrary units of TEFPAH activity (Phe-0.001, Ant-0.01, Flu0.001, Pyr-0.001, BaA-0.10, Chr-0.01, BbF-0.10, BkF-0.1, BaP-1.0, IcdP-0.1, BghiP-0.01, and DahA-1.0 [20-24]) represented as the BaP (BaPeq) equivalent concentration.

$$
\mathrm{BaPeq}=\Sigma \mathrm{CiTEFi}
$$

where BaPeq is $\mathrm{BaP}$ equivalent concentration in ambient air $\left(\mathrm{ng} / \mathrm{m}^{3}\right) ; \mathrm{C}-$ mass concentration of the i-th PAH $\left(\mathrm{ng} / \mathrm{m}^{3}\right)$, and TEFi-toxic equivalent factor of the i-th PAH (dimensionless).

\section{Results}

\subsection{Seasonal and Interannual Dynamics of PAH Concentrations}

The large volume of the obtained data revealed the seasonal dynamics of PAH distribution with the maximum values in winter during low air temperatures, an increase in the amount of fuel burnt, and ground-level inversions. During this period, the total PAH concentrations exceeded summer values by orders of magnitude. In Irkutsk, the total PAH concentrations varied within 17 to $318 \mathrm{ng} / \mathrm{m}^{3}$, with the maximum values in November $\left(145 \mathrm{ng} / \mathrm{m}^{3}\right)$ and December $\left(100 \mathrm{ng} / \mathrm{m}^{3}\right) 2015$ as well as in January $\left(318 \mathrm{ng} / \mathrm{m}^{3}\right)$ and February $\left(254 \mathrm{ng} / \mathrm{m}^{3}\right) 2016$ (Figure 2). At the rural station in the Listvyanka settlement, the concentrations varied during this period within 6.1 to $70 \mathrm{ng} / \mathrm{m}^{3}$. Like in Irkutsk, in Listvyanka, the high values (Figure 2) were recorded in December $2015\left(158 \mathrm{ng} / \mathrm{m}^{3}\right)$ and January $2016\left(70 \mathrm{ng} / \mathrm{m}^{3}\right)$ [25]. In March, with an increase in air temperature, the destruction of ground inversions, and a reduction of the emissions from thermal power plants, $\mathrm{PAH}$ concentrations decreased to $2.0-26 \mathrm{ng} / \mathrm{m}^{3}$ in urban aerosols and to $2.2-7.0 \mathrm{ng} / \mathrm{m}^{3}$-in rural aerosols (Figure 2).

During summer, the further decrease in PAH concentrations took place at both stations, but from July to October 2016, these values were higher in Listvyanka than in Irkutsk. The growth of the PAH concentrations in Listvyanka during this period was due to intense wildfires that engulfed the west coast of the southern basin of Lake Baikal [25]. The smog from these wildfires was present at this station for a long time (Figure 2).

During the next monitoring period (from 2019 to 2020), at the Irkutsk station (Figure 2, Table 1), PAH concentrations varied within lower values (from 0.43 to $71 \mathrm{ng} / \mathrm{m}^{3}$ ) [26]. These values were much lower than the results obtained at abnormally low air temperatures in the winter of 2016. Throughout 2020, a positive air temperature anomaly prevailed in the Irkutsk Region. January was warm owing to the prolonged influence of the active latitudinal zone and the transport of warm air masses from the Atlantic regions. In February, warm air came to the Baikal region from Kazakhstan and the south of West Siberia. Spring began two 
to three weeks earlier than usual in the region, which also affected PAH concentrations in the atmosphere. In May, up to monthly and half monthly precipitation fell in most parts of the region, contributing to the washing out of aerosol particles from the atmosphere, on which PAHs are adsorbed. In March and April, the average monthly PAH concentrations were $3.1 \mathrm{ng} / \mathrm{m}^{3}$ and $1.5 \mathrm{ng} / \mathrm{m}^{3}$, respectively; in May they were $1.4 \mathrm{ng} / \mathrm{m}^{3}$, which is from two to six times lower than in 2016 (from 8.8 to $12 \mathrm{ng} / \mathrm{m}^{3}$ ). From mid-June to mid-July 2020, there was abnormally hot, dry weather in the region. During this period, PAH concentrations varied from 1.8 to $1.2 \mathrm{ng} / \mathrm{m}^{3}$. From September to November, the weather was also warm for this season. The averaged total concentrations of PAHs were relatively low (from 1.7 to $22 \mathrm{ng} / \mathrm{m}^{3}$ ) compared to those in 2016 (from 6.1 to $66 \mathrm{ng} / \mathrm{m}^{3}$ ). Throughout December 2020, warm and cold air masses altered in the region, which affected the variations in the PAH concentrations: $72 \mathrm{ng} / \mathrm{m} 3$ (sampling from 2 December from 9 December 2020), $32 \mathrm{ng} / \mathrm{m}^{3}$ (sampling from 9 to 16 December 2020), $71 \mathrm{ng} / \mathrm{m}^{3}$ (sampling from 16 to 23 December 2020), and $31 \mathrm{ng} / \mathrm{m}^{3}$ (sampling from 23 to 30 December 2020).

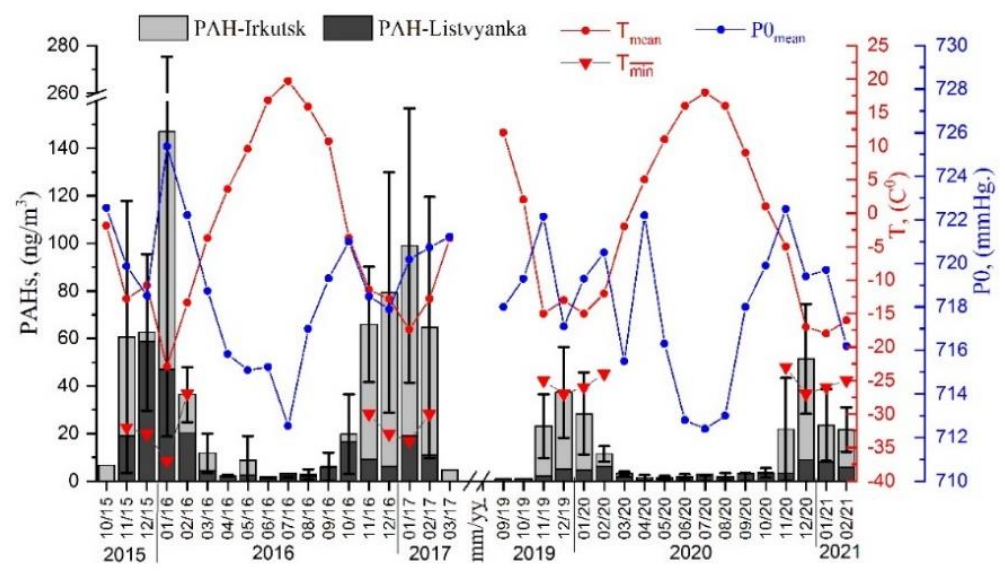

Figure 2. Average monthly total concentrations of PAHs $\left(\mathrm{ng} / \mathrm{m}^{3}\right)$ ( \pm standard deviation), air temperature $\left(\mathrm{T}^{\circ} \mathrm{C}\right)$ and ground-level pressure (P0) in Irkutsk and Listvyanka from 2015 to 2021 [13-15]. The minimum weighted average monthly temperature ( $\mathrm{T} \mathrm{min}$ ) in the frosty period of the year (November-February) is shown by red triangles.

At the Listvyanka station, PAH concentrations in 2020 ranged from 0.5 to $15.6 \mathrm{ng} / \mathrm{m}^{3}$ (Figure 2). At the same time, like in Irkutsk, the maximum values were recorded in December (from 14.6 to $15.6 \mathrm{ng} / \mathrm{m}^{3}$ ); in March and April, the concentrations were $1.7 \mathrm{ng} / \mathrm{m}^{3}$ and $0.7 \mathrm{ng} / \mathrm{m}^{3}$, and in May- $1.3 \mathrm{ng} / \mathrm{m}^{3}$, which was lower than in abnormally cold 2016 (from 2.0 to $4.0 \mathrm{ng} / \mathrm{m}^{3}$ ) [26]. In summer and autumn, there was a further decrease in PAH concentrations at the Listvyanka station; the concentrations in these months were approximately the same (from 3.0 to $3.4 \mathrm{ng} / \mathrm{m}^{3}$ ).

In recent years, the network of monitoring stations for the determination of PAHs in the atmosphere has been expanding in the cities of many countries, and the list of some of their compounds to be determined has been increasing. Our results on the concentrations of these environmental toxicants at the two reference stations in Irkutsk and Listvyanka of the Southern Baikal region were lower than in the cities of Central and North China but higher than in the cities of Europe, Japan, and the United States [9,27-35].

\subsection{Analysis of PAH Sources}

One of the conventional methods for identifying PAH sources is to determine the concentration ratios of PAH isomers in aerosols and to compare them with the data on the values of these ratios in the sources [4]. The method of diagnostic ratios was used to identify sources of PAH emissions in Irkutsk and Listvyanka. It is known from the literature that the fluoranthene/(fluoranthene + pyrene) ratio for petrogenic sources is $<0.4$; if it is $>0.4$, the sources are pyrogenic [4]. The ratio calculated in the aerosol from Irkutsk (from 0.44 to 
0.60, Table 2) and on the coast of Lake Baikal (from 1.2 to 16.9) indicated combustion of coal and wood [4]. The indeno $(1,2,3-\mathrm{c}, \mathrm{d})$ pyrene/indeno(1,2,3-c,d)pyrene + benzo(g,h,i)perylene ratio $<0.5$ indicates combustion of liquid fuel, and that $>0.5-$ combustion of coal and wood. Based on this ratio, urban sources in the region can be divided into two types: combustion of coal and wood in autumn and winter (from 0.5 to 0.6 ) and combustion of more liquid fuel in spring and summer (from 0.3 to 0.4 ). In Listvyanka, the main PAH source is the combustion of liquid fuel (from 0.3 to 0.4 ). In this tourist settlement, mazut, a fuel oil, is used for local boiler houses, and in the coastal water area, a large number of ships operate on diesel fuel. There is a large traffic of vehicles on the highway passing along the lake coast. A diagnostic benzo(a)pyrene/benzo(g,h,i)perylene ratio below 0.6 also seems to indicate vehicle emissions and that above 0.5 - stationary sources [4]. In aerosol samples from Irkutsk, the sources of PAH emissions are rather identified as emissions from stationary sources (form 0.6 to 46.7); in Listvyanka, the sources of PAH emissions are mostly attributed to vehicles ( 0.49 on average, Table 2$)$, but the influence of stationary sources is also present (from 0.3 to 1.2). According to [5,6,18], for aerosol samples collected near the pollution sources, the benzo(e)pyrene/benzo(e)pyrene + benzo(a)pyrene ratio is 0.50 to 0.57; at a significant distance from PAH sources, the ratio ranges from 0.70 to 0.83 [6-8]. The calculated benzo(a)pyrene ratio in urban aerosol (from 0.4 to 0.7 ) indicated both emissions from the close and distant sources; in rural areas, all sources of PAH emissions were distant (from 0.6 to 0.9 ).

We analysed the percentage of individual PAHs at the observation stations for the study period. In aerosol samples, phenanthrene, fluoranthene, pyrene, benzo(b)fluoranthene, benzo(k)fluoranthene prevailed among individual PAHs (Figure 3). The percentage of fluoranthene and pyrene in aerosol associated with coal combustion [4] reached 21 to $55 \%$ in winter. The concentrations of chrysene and benzo(b)fluoranthene, the dominant compounds in the emission from stationary sources in the urban atmosphere were higher in winter (from 18 to $28 \%$ ) than in summer (from 5 to $15 \%$ ). In the atmosphere of the Listvyanka settlement, the same compounds accounted for 12 to $21 \%$ in summer and 10 to $31 \%$ in winter. The total percentage of benzo(g,h,i)perylene, indeno(1,2,3-c,d)pyrene and dibenz(a,h)anthracene, the indicators of urban air pollution by vehicles, reached 3 to $12 \%$ in summer and 6 to $16 \%$ in winter. On the Baikal coast, the concentration of these substances was 7 to $19 \%$ in summer and 11 to $23 \%$ in winter. The relative concentration of phenanthrene prevailing during combustion of liquid fuels [19] or emissions from the petrochemical industry reached $7 \%$ in winter aerosols from Listvyanka and 31\% in summer ones.

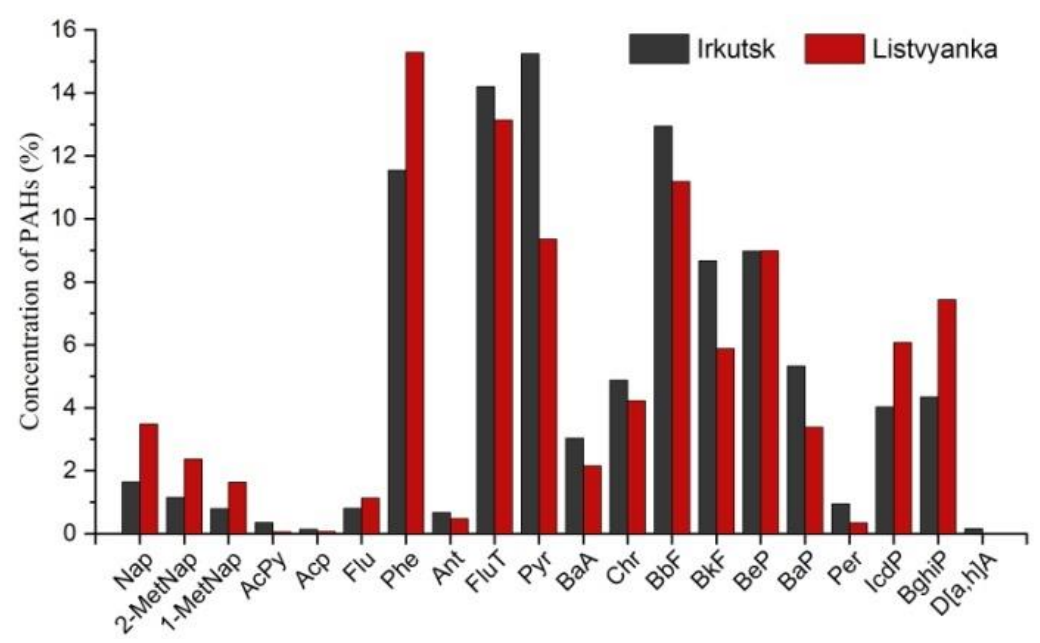

Figure 3. Average percentage of individual PAHs in aerosols at stations Irkutsk and Listvyanka (Southern Baikal region) from 2015 to 2021. 
In the cold season, the PAH percentage in the aerosol composition at the two monitoring stations differed significantly (Figure 4). In Irkutsk, the PAH group with four, five and six benzene rings (92\%) predominated; while in Listvyanka, the proportion of these PAHs was lower (84\%). In spring and summer, the proportion of PAHs with two and three benzene rings increased to $32 \%$ at both stations. During this period, anticyclone processes were activated over the Baikal region; wind speeds intensified and turbulent mixing in the atmosphere increased. Most of the region was dominated by westerly and northwesterly air masses that transported pollutants from the industrial cities of the region along the valley of the Angara River to the central ecological zone of the lake. Figure 5 shows that in spring and summer the percentage of PAHs in Listvyanka and Irkutsk is similar, indicating their common sources.

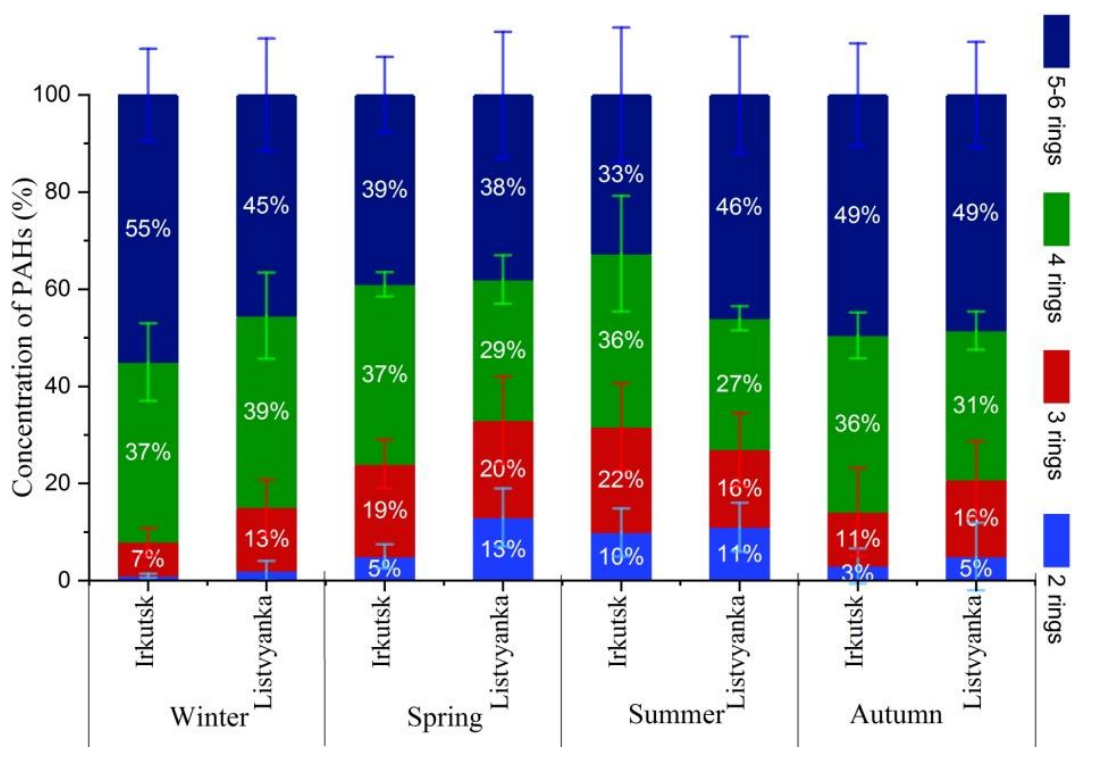

Figure 4. Average percentage of individual PAHs ( \pm standard deviation) in aerosols at stations Irkutsk and Listvyanka (Southern Baikal region) from 2015 to 2021.

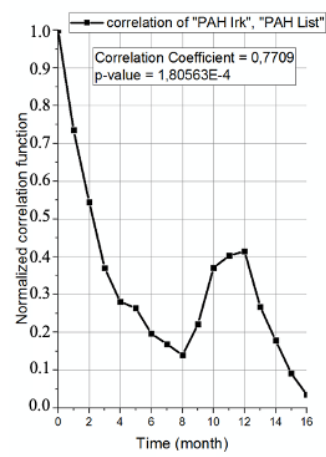

(a)

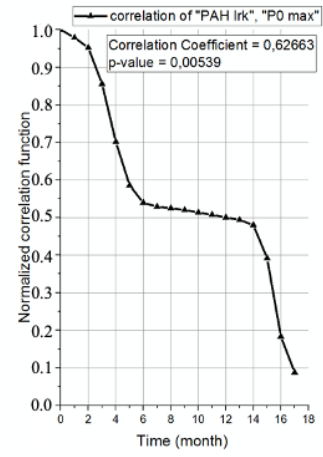

(b)

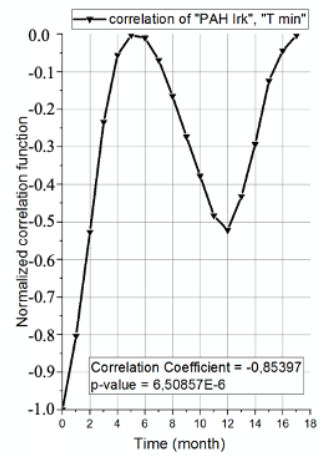

(c)

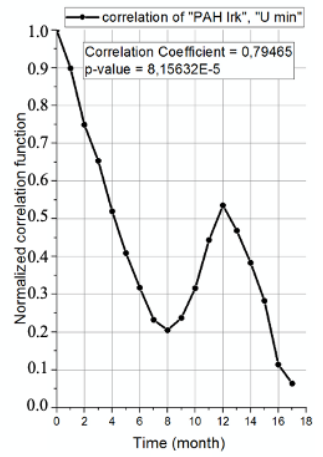

(d)

Figure 5. Normalisedcross-correlation functions between (a) the average monthly total PAHs in Irkutsk and Listvyanka, (b) the total PAHs and P0 max, (c) the total PAHs and Tmin, (d) the total PAHs and Umin.

\subsection{Characteristics of Meteorological Parameters}

Based on the archived meteorological data (ground air temperature, T; pressure, P0; and humidity, U) from the weather station of the Irkutsk airport and the weather station located near the sampling site in the Listvyanka settlement, we carried out a comprehensive analysis of weather conditions for the entire period of PAH monitoring in the atmospheric air at the reference stations. The series of meteorological parameters were averaged over the days of the PAH sampling for time comparison. To assess the intraseasonalvariability, all 
data were averaged over months (Figure 2). Analysis of the series of weekly data on PAHs and meteorological parameters revealed the main contribution to the total concentration of these environmental toxicants for a month from the weekly observations that recorded the extreme values of meteorological parameters (maximum atmospheric pressure, P0max; minimum air temperature, Tmin; and minimum humidity, Umin). For example, about $45 \%$ of PAHs in Irkutsk were determined in the first week of December 2019 with the minimum air temperatures and the maximum humidity values. In December 2020, PAHs were also recorded for two weeks with the minimum air temperatures and the maximum pressure.

To assess the regularities of the statistical relationship of the total PAH concentrations in the atmosphere with weather conditions, we took into account cross-correlation functions of the series of the average PAH values for a month and extreme P0max, TminandUmin values in the corresponding month (Figure 5). The estimates shown in Figure 5 were carried out only for Irkutsk, but the high correlation coefficient between the series of the total PAH concentrations in Irkutsk and Listvyanka $(r=0.77$, Figure 5a) indicates the common factors that influence the dynamics of the PAH concentrations in the ground-level atmosphere at the monitoring stations located $70 \mathrm{~km}$ apart. Such distances can cover the movement of air masses in the atmosphere of synoptic scales. Air pressure (P0) is the main indicator of cyclonic changes in the atmosphere. The cross-correlation function between PAHs and P0max (Figure 5b) indicates a stable relationship during seasonal semi-annual periods ( $\approx 6$ months) with a significant $r=0.63$. The cross-correlation of ground-level pressure (P0) values at both stations (Irkutsk and Listvyanka) has a high statistic relationship, $r=0.92$, which confirms the influence of this common synoptic factor on the dynamics of $\mathrm{PAH}$ concentrations.

Changes in meteorological parameters introduced by the cyclonic replacement of air masses reveal the relationship between the maximum and minimum PAH values and the extreme Tmin and Uminvalues in more contrast. For example, a high negative value of the correlation coefficient, $\mathrm{r}=-0.85$ (Figure $5 \mathrm{c}$ ), indicates the dominant factor in the growth of the total PAH concentrations in the atmosphere with a decrease in negative temperatures in winter. The positive correlation coefficient, $r=0.79$ (Figure $5 \mathrm{~d}$ ), between PAHs and Umin indicates the significant growth of the PAH concentrations with an increase in the minimum relative humidity. All correlation functions reveal the maximum relationship of PAHs with meteorological parameters in winter (clear basic maximum of the shift occurs in December) and the minimum relationship in summer (minimum values in summer are blurred from May to August). Table 3 shows the summary data on the correlation coefficients between the PAH values and meteorological parameters at the reference sampling stations of Irkutsk and Listvyanka in the Southern Baikal region.

Table 3. Correlation coefficients between PAH values and meteorological parameters at the sampling stations in Irkutsk and Listvyanka (Southern Baikal region) from 2015 to 2019.

\begin{tabular}{cccccc}
\hline & $\begin{array}{c}\text { PAH } \\
\text { (Irkutsk) }\end{array}$ & $\begin{array}{c}\text { PAH } \\
\text { (Listvyanka) }\end{array}$ & P0 Max & Tmin & Umin \\
\hline $\begin{array}{c}\text { PAH } \\
\text { (Irkutsk) }\end{array}$ & 1 & 0.77 & 0.63 & -0.85 & 0.79 \\
\hline $\begin{array}{c}\text { PAH } \\
\text { (Listvyanka) }\end{array}$ & 0.77 & 1 & 0.51 & -0.71 & 0.83 \\
\hline
\end{tabular}

We calculated the trajectories of air masses for the study period in the analysed area (station Listvyanka), which we combined into four sectors of geographical zoning. We also calculated the percentage of recurrence of incoming trajectories by sectors for abnormally cold 2016 and warm 2020 (Figure 6). The first sector (I) includes trajectories of westerly and northwesterly air masses that are transported above the industrial areas of West Siberia and East Siberia and contribute to a significant influx of polluting air masses to the water area of the lake. The second sector (II) includes trajectories of easterly and northeasterly air masses 
that are formed above the Arctic Ocean where there are no anthropogenic sources. The third sector (III) consists of trajectories of southeasterly air masses, including the cases of "local circulation". The fourth sector (IV) consisting of trajectories of southerly and southwesterly air masses is the second most important in 2016 and 2020. Large anthropogenic sources of pollution in this sector are located at a considerable distance from the receptor region. In 2016, an abnormally cold year, the recurrence percentage of incoming trajectories was distributed by the sectors as follows: I (71\%), >IV (15\%), > II (10\%), and >III (4\%, Figure 6). In abnormally warm 2020, the proportion of northwesterly air masses (sector I, 65\%) decreased, and the proportion of southwesterly air masses increased (sector IV, 20\%, Figure 6).

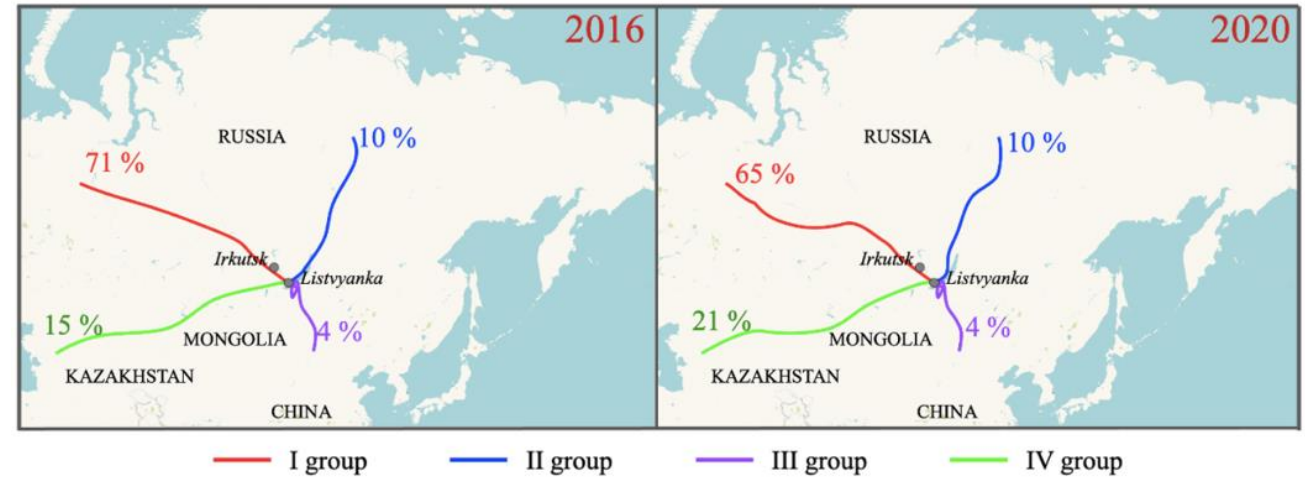

Figure 6. Geographical zoning of back trajectories of air masses entering the basin of Lake Baikal in 2016 and 2020 (I-W; W-NW; NW; N-NW; II-N; NE-E; NE; E-NE; III-E; E-SE; SE; S-SE; LC; IV-S; S-SW; SW; W-SW) (created by author) [16].

\subsection{Human Health RiskAssessment Associatedwith PAH Concentrations in the Atmospheric Air}

Benzo(a)pyrene (BaP) serves as a marker in the monitoring of PAHs because it has the highest carcinogenic properties. In Russia, the limits of the average diurnal concentration of $\mathrm{BaP}(\mathrm{MPC})$ are established at $1.0 \mathrm{ng} / \mathrm{m}^{3}$; WHO recommends the average annual concentrations of BaP below $0.12 \mathrm{ng} / \mathrm{m}^{3}$ [36]. However, at many monitoring stations of the world, the average annual concentrations exceed this level [37]. In Irkutsk, in cold 2016, there was a 5 to 28-fold excess of MPC for BaP in winter, 1.1 to 24-fold excess in spring and 1.1 to 6.8-fold in autumn. On the Baikal coast, in the Listvyanka settlement, a 1.1 to 8.9-fold excess of MPC for BaP was determined only in winter. During this period, the average annual concentrations of BaP were $3.2 \mathrm{ng} / \mathrm{m}^{3}$ in Irkutsk and $0.49 \mathrm{ng} / \mathrm{m}^{3}$ in Listvyanka, which is much higher than the values established by WHO. In warmer 2020, the average annual concentrations of BaP in Irkutsk and Listvyanka were much lower, 1.19 and $0.16 \mathrm{ng} / \mathrm{m}^{3}$, respectively, but higher than the values established by WHO.

As a comparison, high BaP concentrations were observed both during the heating season (from 4 to $14 \mathrm{ng} / \mathrm{m}^{3}$ ) and in the rest of the year (from 2.4 to $4.7 \mathrm{ng} / \mathrm{m}^{3}$ ) in the cities of Poland [38]. The average annual concentrations of $\mathrm{BaP}$ were also exceeded in the Czech cities $\left(0.39 \mathrm{ng} / \mathrm{m}^{3}\right)$ [39]. This situation was not observed in other European regions. For instance, the studies conducted in the cities of Spain and Italy revealed that the $\mathrm{BaP}$ concentrations in winter ranged from 0.054 to $0.240 \mathrm{ng} / \mathrm{m}^{3}$ [40] and from 0.2 to $0.47 \mathrm{ng} / \mathrm{m}^{3}$ [41], respectively, and were even lower in summer. High BaP concentrations were determined in the cities of China $\left(30 \mathrm{ng} / \mathrm{m}^{3}\right)$ [12] and India $\left(9.9 \mathrm{ng} / \mathrm{m}^{3}\right)$ [42]. At the same time, the average annual concentration also considerably exceeded the permissible norm $\left(6.8 \mathrm{ng} / \mathrm{m}^{3}\right)$ [12]. The annual concentrations of BaP in the atmosphere of Kanazava (Japan) were 0.040 to $0.026 \mathrm{ng} / \mathrm{m}^{3}$ with the maximum concentration of $0.12 \mathrm{ng} / \mathrm{m}^{3}$, which does not exceed the level established by WHO.

The toxicity of PAHs in the atmosphere in terms of their effect on humans was assessed by the concentration of BaP toxic equivalent $[20,21]$. The order of the BaPeq concentrations for 12 PAHs (Phe, Ant, Flu, Pyr, BaA, Chr, BbF, BkF, BaP, IcdP, BghiP, and DahA) at the two monitoring stations in the Southern Baikal region, which was calculated using 
toxic equivalent factors of individual PAHs (TEFPAH), decreased from winter to summer (Table 4) similar to the order of the concentrations of 11 PAHs. Moreover, BaP was the largest contributor to air pollution in winter, spring and autumn. The same pattern in the distribution of BaPeq by seasons was revealed for the cities of Japan, China, India, and Europe (Table 4).

Table 4. Concentrations of $\mathrm{BaPeq}\left(\mathrm{ng} / \mathrm{m}^{3}\right)$ and $\mathrm{BaP} / \mathrm{BaPeq}(\%)$ in the atmospheric air by seasons in different regions of the world.

\begin{tabular}{|c|c|c|c|c|c|}
\hline Sampling Stations & & Winter & Spring & Summer & Autumn \\
\hline \multirow{2}{*}{$\begin{array}{l}\text { Irkutsk, Southern Baikal } \\
\text { region, Russia }\end{array}$} & BaPeq & $2.1-38$ & $0.1-1.8$ & $0.1-0.2$ & $7.9-10$ \\
\hline & $\mathrm{BaP} / \mathrm{BaPeq}(\%)$ & $61-70$ & $38-65$ & $30-31$ & $30-66$ \\
\hline \multirow{2}{*}{$\begin{array}{l}\text { Listvyanka, Southern } \\
\text { Baikal region, Russia }\end{array}$} & BaPeq & $0.17-1.9$ & $0.06-0.25$ & $0.05-0.25$ & $0.06-1.6$ \\
\hline & $\mathrm{BaP} / \mathrm{BaPeq}(\%)$ & $54-55$ & $49-53$ & 48 & $41-60$ \\
\hline \multirow{2}{*}{ Urumqi, China [12] } & BaPeq & $13-84$ & $1.1-10$ & $1.9-2.0$ & $1.7-20$ \\
\hline & $\mathrm{BaP} / \mathrm{BaPeq}(\%)$ & $17-36$ & $28-34$ & $47-41$ & $15-16$ \\
\hline \multirow{2}{*}{ Delhi, India [42] } & BaPeq & 28.9 & & 17.6 & \\
\hline & $\mathrm{BaP} / \mathrm{BaPeq}(\%)$ & 34 & & 29 & \\
\hline \multirow{2}{*}{ Kanazawa, Japan [35] } & BaPeq & 0.060 & 0.070 & 0.028 & 0.059 \\
\hline & $\mathrm{BaP} / \mathrm{BaPeq}(\%)$ & 62 & 62 & 62 & 62 \\
\hline \multirow{2}{*}{ Florence, Italy [41] } & BaPeq & $2.7-5.4$ & & $0.41-1.54$ & \\
\hline & $\mathrm{BaP} / \mathrm{BaPeq}(\%)$ & $17-18$ & & $12-13$ & \\
\hline \multirow{2}{*}{ Madrid, Spain [40] } & BaPeq & $0.12-0.5$ & & $0.10-0.12$ & \\
\hline & $\mathrm{BaP} / \mathrm{BaPeq}(\%)$ & $45-47$ & & $22-28$ & \\
\hline \multirow{2}{*}{ Katowice, Poland [38] } & BaPeq & 18-106 & & $5.3-15.5$ & \\
\hline & $\mathrm{BaP} / \mathrm{BaPeq}(\%)$ & $13-67$ & & $34-62$ & \\
\hline
\end{tabular}

\section{Conclusions}

Based on the long-term studies obtained at two reference stations, Irkutsk and Listvyanka (Southern Baikal region), exposed to different levels of technogenic air pollution, we determined the seasonal and interannual dynamics of PAH concentrations in the atmospheric air and carried out a comprehensive analysis of meteorological conditions during the observations. This study revealed high correlations between air temperature, atmospheric pressure, inversions, and PAH concentration in the air during winter. The main sources of PAHs in the Southern Baikal region are emissions from thermal power plants during burning coal and from burning wood for stove heating, combustion of liquid fuel (mazut) in low-capacity boiler houses, and diesel fuel and petrol of vehicles, as well as wildfires in the summer of 2016.

The average annual concentrations of PAHs in abnormally warm 2020 were three times lower than the values obtained in colder 2016. The highest PAH values in the atmospheric air were determined in January 2016 when an Arctic anticyclone with abnormally low air temperatures, high pressure, and low inversion came to the Baikal region. During this period, we recorded a 27-fold excess of MPC for benzo(a)pyrene.

We calculated contributions from different sources of PAHs to air pollution using the method of diagnostic ratios. The concentrations of two- and three-ring PAHs tended to increase from winter to summer at both stations, and their origin from the same sources in this period of the year was similar. The toxic concentrations of aerosol (BaPeq) increased from the warm season (summer) to the cold season (winter) when the proportion of benzo(a)pyrene was the highest. The percentage of the transport of anthropogenic aerosol from industrial sources to the central ecological zone of Lake Baikal was 65 to $71 \%$. 
Author Contributions: Conceptualization, I.M.; Formal analysis, I.M. and I.P.; Funding acquisition, T.K.; Methodology, I.P. and E.M.; Software, I.P. and M.S.; Validation, T.K.; Writing-review \& editing, I.M. All authors have read and agreed to the published version of the manuscript.

Funding: This study was carried out within the framework of the LIN SB RAS state project № 02792021-0014 «Investigation of the role of atmospheric precipitation on the aquatic and terrestrial ecosystems of the Lake Baikal basin, identification of sources of atmospheric pollution».

Institutional Review Board Statement: Not applicable.

Informed Consent Statement: Not applicable.

Data Availability Statement: Not applicable.

Acknowledgments: This study was conducted within the framework of the Collective Instrumental Center "Ultramicroanalysis" Limnological Institute SB RAS.

Conflicts of Interest: The authors declare no conflict of interest.

\section{References}

1. Federal Law of 1 May 1999 № 94-FL “On the Protection of Lake Baikal”. Available online: https://base.garant.ru/2157025/ (accessed on 8 December 2021).

2. State Report “On the State and Environmental Protection of the Russian Federation in 2018”. Available online: https: //www.mnr.gov.ru/docs/o_sostoyanii_i_ob_okhrane_okruzhayushchey_sredy_rossiyskoy_federatsii/gosudarstvennyy_ doklad_o_sostoyanii_i_ob_okhrane_okruzhayushchey_sredy_rossiyskoy_federatsii_v_2018_/ (accessed on 8 December 2021).

3. Gorshkov, A.G.; Izosimova, O.N.; Kustova, O.V.; Marinaite, I.I.; Galachyants, Y.P.; Sinyukovich, V.N.; Khodzher, T.V. Wildfires as a source of PAHs in surface waters of background areas (Lake Baikal, Russia). Water 2021, 13, 2636. [CrossRef]

4. Tobiszewski, M.; Namiesnik, J. PAH diagnostic ratios for the identification of pollution emission sources. Environ. Pollut. 2012, 162, 110-119. [CrossRef] [PubMed]

5. Omar, N.Y.V.J.; Abas, M.R.B.; Ketuly, K.A.; Tahir, N.M. Concentrations of PAHs in atmospheric particles (PM10) and roadside soil particles collected in Kuala Lumpur, Malaysia. Atmos. Environ. 2002, 36, 247-254. [CrossRef]

6. Gorshkov, A.G.; Marinaite, I.I.; Zhamsueva, G.S.; Zayakhanov, A.S. Benzopyrene isomer ratioin organic reaction of aerosols over water surface of Lake Baikal. J. Aerosol Sci. 2004, 2, 1059-1060. [CrossRef]

7. Fang, M.; Zeng, M.; Wang, F.; To, K.L.; Jaafar, A.B.; Tong, S.L. The solvent-extractable organic compounds in the Indonesia biomass burning aerosols-characterization studies. Atmos. Environ. 1999, 33, 783-795. [CrossRef]

8. Zeng, M.; Wan, T.S.M.; Fang, M.; Wang, F. Characterization of the non-volatile organic compounds in the aerosols of Hong Kong-identification, abundance and origin. Atmos. Environ. 1997, 31, 227-237. [CrossRef]

9. Yang, L.; Suzuki, G.; Zhang, L.; Zhou, Q.; Zhang, X.; Xing, W.; Shima, M.; Yoda, Y.; Nakatsubo, R.; Hiraki, T.; et al. The characteristics of polycyclic aromatic hydrocarbons in different emission source areas in Shenyang, China. Int. J. Environ. Public Health 2019, 16, 2817. [CrossRef]

10. Hayakawa, K.; Tang, N.; Nagato, E.G.; Toriba, A.; Sakai, S.; Kano, F.; Goto, S.; Endo, O.; Arashidani, K.; Kakimoto, H. Long term trends in atmospheric concentrations of polycyclic aromatic hydrocarbons and nitropolycyclicaromatichydrocarbons: Astudy of Japanese cities from 1997 to 2014. Environ. Pollut. 2018, 233, 474-482. [CrossRef]

11. GN 2.1.6.3492-17 “On Approval of Hygienic Standards “Maximum Permissible Concentrations (MPC) of Pollutants in the Air of Urban and Rural Settlements" (as amended on 31 May 2018). Resolution of the Chief State Sanitary Physician of the Russian Federation of 22 December 2017 №165. Available online: https:/ / www.garant.ru/products/ipo/prime/doc/71750374/ (accessed on 8 December 2021).

12. Rekefu, S.; Talifu, D.; Gao, B.; Turap, Y.; Maihemuti, M.; Wang, X.; Abulizi, A. Polycyclic aromatic hydrocarbons in PM2.5 and PM2.5-10 in Urumqi, China: Temporal variations, health risk, and sources. Atmosphere 2018, 9, 412. [CrossRef]

13. Arctic and Antarctic Research Institute Website. Available online: https:/ / www.aari.ru/ (accessed on 8 December 2021).

14. Weather Archive rp5. Available online: http:/ /rp5.ru/ (accessed on 8 December 2021).

15. University of Wyoming Website. Available online: http://weather.uwyo.edu/ upperair/sounding.html/ (accessed on 8 December 2021).

16. National Oceanic and Atmospheric Administration. Lagrangian Integrated Trajectory Model. Available online: https://ready.arl. noaa.gov/hypub-bin/trajtype.pl (accessed on 18 September 2021).

17. Ravindra, K.; Sokhi, R.; Van Grieken, R. Atmospheric polycyclic aromatic hydrocarbons: Source attribution, emission factors and regulation. Atmos. Environ. 2008, 42, 2895-2921. [CrossRef]

18. Nielsen, T.; Jorgensen, H.E.; Larsen, J.C.; Poulsen, M. City air pollution of polycyclic hydrocarbons and other mutagens: Occurrence, sources and health effects. Sci. Total Environ. 1996, 189-190, 41-49. [CrossRef]

19. Masclet, P.; Hoyau, V.; Jaffrezo, J.L.; Cachier, H. Polycyclic aromatic hydrocarbon deposition on the ice sheet of Greenland. Part I: Superficial snow. Atmos. Environ. 2000, 34, 3195-3207. [CrossRef] 
20. Malcolm, H.M.; Dobson, S. The Calculation of an Environmental Assessment Level (EAL) for Atmospheric PAHs Using Relative Potencies; Department of the Environment: London, UK, 1994; pp. 34-46.

21. Hayakawa, K. Polycyclic Aromatic Hydrocarbons: Environmental Behavior and Toxicity in East Asia; Springer: Berlin/Heidelberg, Germany, 2018; pp. 1-274.

22. Liu, J.; Man, R.; Ma, S.; Li, J.; Wu, Q.; Peng, J. Atmospheric levels and health risk of polycyclic aromatic hydrocarbons (PAHs) bound to PM2.5 in Guangzhou, China. Mar. Pollut. Bull. 2015, 100, 134-143. [CrossRef] [PubMed]

23. Behymer, T.D.; Hites, R.A. Photolysis of polycyclic aromatic hydrocarbons adsorbed on simulated atmospheric particulates. Environ. Sci. Technol. 1985, 19, 1004-1006. [CrossRef]

24. Masclet, P.; Mouvier, G.; Nikolaou, K. Relative decay index and sources of polycyclic aromatic hydrocarbons. Atmos. Environ. 1986, 20, 439-446. [CrossRef]

25. Marinaite, I.; Penner, I.; Khodzher, T. Effect of meteorological conditions on the distribution of PAHs in the atmosphere of the southern Baikal region. In Proceedings of 26th International Symposium on Atmospheric and Ocean Optics, Atmospheric Physics; SPIE: Bellingham, WA, USA, 2020.

26. Marinaite, I.; Penner, I.; Molozhnikova, Y.; Shikhovtsev, M.; Obolkin, V.; Kustova, O.; Khodzher, T. PAHs and Meteorological Parameters in the Atmosphere of the Southern Baikal Region from 2019 to 2021. In Proceedings of the 27th International Symposium on Atmospheric and Ocean Optics, Atmospheric Physics; SPIE: Bellingham, WA, USA, 2021.

27. Cetin, B.; Ozturk, F.; Keles, M.; Yurdakul, S. PAHs and PCBs in an eastern Mediterranean megacity, Istanbul: Their spatial and temporal distributions, air-soil exchange and toxicological effects. Environ. Pollut. 2017, 220, 1322-1332. [CrossRef]

28. Franco, J.; de Resende, F.; de Almeida Furtado, L.; Brasil, F.; Eberlin, N.; Netto, P. Polycyclic aromatic hydrocarbons (PAHs) in street dust of Rio de Janeiro and Niterói, Brazil: Particle size distribution, sources and cancer risk assessment. Sci. Total Environ. 2017, 599-600, 305-313. [CrossRef]

29. Hamid, N.; Syed, H.; Junaid, M.; Mahmood, A.; Li, J.; Zhang, G.; Naseem-Malik, R. Elucidating the urban levels, sources and health risks of polycyclic aromatic hydrocarbons (PAHs) in Pakistan: Implications for changing energy demand. Sci. Total Environ. 2018, 619-620, 165-175. [CrossRef]

30. Yang, J.; Xu, W.; Cheng, H. Seasonal variations and sources of airborne polycyclic aromatic hydrocarbons (PAHs) in Chengdu, China. Atmosphere 2018, 9, 63. [CrossRef]

31. Byambaa, B.; Yang, L.; Matsuki, A.; Nagato, E.G.; Gankhuyang, K.; Chuluunpurev, B.; Banzragch, L.; Chonokhuu, S.; Tang, N.; Hayakawa, K. Sources and characteristics of polycyclic aromatic hydrocarbons in ambient total suspended particles in Ulaanbaatar city, Mongolia. Int. J. Environ. Res. Public Health 2019, 16, 442. [CrossRef]

32. Hu, H.; Tian, M.; Zhang, L.; Yang, F.; Peng, C.; Chen, Y.; Shi, G.; Yao, X.; Jiang, C.; Wang, J. Sources and gas-particle partitioning of atmospheric parent, oxygenated, and nitrated polycyclic aromatic hydrocarbons in a humidcity in southwest China. Atmos. Environ. 2019, 206, 1-10. [CrossRef]

33. Emine, A.; Fatma, E. Atmospheric polycyclic aromatic hydrocarbons (PAHs) at two sites, in Bursa, Turkey: Determination of concentrations, gas-particle partitioning, sources, and health risk. Arch. Environ. Contam. Toxicol. 2020, 78, 350-366.

34. Yang, L.; Zhang, X.; Xing, W.; Zhou, Q.; Zhang, L.; Wu, Q.; Zhou, Z.; Chen, R.; Toriba, A.; Hayakawa, K.; et al. Yearly variation in characteristics and health risk of polycyclic aromatic hydrocarbons and nitro-PAHs in urban Shanghai from 2010-2018. Environ. Sci. 2021, 99, 72-79. [CrossRef] [PubMed]

35. Hayakawa, K.; Tang, N.; Xing, W.; Oanh, P.K.; Hara, A.; Nakamura, H. Concentrations and sources of atmospheric PM, polycyclic aromatic hydrocarbons and nitropolycyclicaromatichydrocarbons in Kanazawa, Japan. Atmosphere 2021, 12, 256. [CrossRef]

36. WHO. Review of Evidence on Health Aspects of Air Pollution-REVIHAAP Project: Final Technical Report, WHO Regional Office for Europe. 2013. Available online: https://www.euro.who.int/en/health-topics/environment-and-health/air-quality/ publications / 2013/review-of-evidence-on-health-aspects-of-air-pollution-revihaap-projectfinal-technical-report (accessed on 18 September 2021).

37. European Environment Agency. Annual Mean Bap Concentrations in 2018. 2020. Available online: https://www.eea.europa.eu/ data-and-maps/figures/annual-mean-bap-concentrations-in-4 (accessed on 18 September 2021).

38. Kozielska, B.; Rogula-Kozłowska, W.; Klejnowski, K. Seasonal variations in health hazards from polycyclic aromatic hydrocarbons bound to submicrometerparticles at three characteristic sites in the heavily polluted Polish Region. Atmosphere 2015, 6, 1-20. [CrossRef]

39. Křo̊mal, K.; Mikuška, P.; Večeřa, Z. Polycyclic aromatic hydrocarbons and hopanes in PM1 aerosols in urban areas. Atmos. Environ. 2013, 67, 27-37. [CrossRef]

40. Mirante, F.; Alves, C.; Pio, C.; Pindado, O.; Perez, R.; Revuelta, M.A.; Artiñano, B. Organic composition of size segregated atmospheric particulate matter, during summer and winter sampling campaigns at representative sites in Madrid, Spain. Atmos. Res. 2013, 132-133, 345-361. [CrossRef]

41. Martellini, T.; Giannoni, M.; Lepri, L.; Katsoyiannis, A.; Cincinelli, A. One year intensive PM 2.5 bound polycyclic aromatic hydrocarbons monitoring in the area of Tuscany, Italy. Concentrations, source understanding and implications. Environ. Pollut. 2012, 164, 252-258. [CrossRef]

42. Singh, D.P.; Gadi, R.; Mandal, T.K. Characterization of particulate-bound polycyclic aromatic hydrocarbons and trace metals composition of urban air in Delhi, India. Atmos. Environ. 2011, 45, 7653-7663. [CrossRef] 